Araştırma Makalesi / Research Article

\title{
THE DEVELOPMENT OF SERVICE SECTOR IN TURKEY AFTER 2001 CRISIS

\author{
Cengizhan YILDIRIM*
} \\ 2001 KRIZİ SONRASI TÜRKIYYE'DE HIZMETLER SEKTÖRÜNÜN GELIŞIMII
}

\begin{abstract}
Despite having the largest share of national income in today's modern economy, the services sector remains in the shadow of industry. Therefore, service sector must be analysed in a more detailed way. The aim of this article is to analyse the development of service sector in Turkey after 2001 Crisis. In accordance with this aim, service sector was theoretically mentioned and economic developments occurring in Turkey after 2001 Crisis were discussed. Later on, development of sub-sectors of service sectors, its share in GDP and employment, and external balance of service sector was analysed; finally, the size of service sector in Turkey was compared to the sizes of selected countries.
\end{abstract}

Keywords: Service Sector, Turkish Economy, 2001 Crisis.

\section{$\ddot{\mathbf{O} z}$}

Günümüz modern ekonomilerinde milli gelir içinde en fazla paya sahip olmasına rağmen hizmetler sektörü, sanayi sektörünün gölgesinde kalmaktadır. Dolayısıyla hizmetler sektörünün daha iyi analiz edilmesi gerekir. Bu makalenin amacı da Türkiye'de hizmetler sektörünün 2001 Krizi sonrası gelişimi incelemektir. $\mathrm{Bu}$ amaç doğrultusunda hizmetler sektörü kuramsal olarak ifade edilmiş ve 2001 Krizi sonrası Türkiye'de ekonomik gelişmeler ifade edilmiştir. Daha sonra hizmetler sektörünün alt-sektörlerinin gelişimi, GSYH ve istihdamdaki payı, hizmetler sektörünün dış dengesi analiz edilmiş, son olarak Türkiye'de hizmetler sektörünün büyüklüğü seçilen ülkelerle karş1laştırılmıştır.

Anahtar Kelimeler: Hizmetler Sektörü, Türkiye Ekonomisi, 2001 Krizi.

\section{Introduction}

With the crisis experienced in the middle of 1970's, the share of service sector in the produced added value has started to increase by gaining a new momentum. Called post-industrial period, the significant increase of the share of service sector in domestic income has started to find a place

\footnotetext{
* Dr. Öğr. Üyesi, Bolu Abant İzzet Baysal Üniversitesi, İİBF, İktisat Bölümü, eposta: yildirim_c@ibu.edu.tr, https://orcid.org/0000-0002-3812-1188.

Makale Gönderim Tarihi: 11.04.2019 https://dx.doi.org/10.11616/basbed.v19i47045.552648 Makale Kabul Tarihi $\quad$ : 28.06.2019
} 
for itself in analyses in this period. In 1980's, many author drew attention to this situation; however, a services revolution was not mentioned in these years but after its rapid movement in 1990's, a services revolution can be mentioned. When someone writes "service economy" or "service sector" on Google, generally old articles can be seen but when someone writes "service revolution" more recent articles can be accessed.

In today's developed countries, the share of service sector in GDP has already reached up to $70 \%$ and event to $80 \%$ in some countries. Developing countries have also been rapidly progressing in the same way. Therefore, a sector which has such a majority in economies must be analysed and understood in a better way.

The aim of this study is to analyse service sector in Turkey and to compare it with other countries. In accordance with this aim, in the first part, the definition of service sector is provided and its increasing importance in economies is mentioned. In the second part, the development of service sectors in the last 15 years is discussed in relation to its sub-sectors. It was determined that shares of sub-sectors in GDP have varied. After the third part where Turkey is compared with some selected countries, the study ends with conclusion and suggestions parts.

\section{Theoretical Explanations about Service Sector}

In traditional analyses, economies are analysed under three main titles as being primary (agriculture), secondary (industry), and tertiary (services). Primary sectors consist of sectors which are based on raw material production such as agriculture, husbandry, forestry, and mining; secondary sectors consist of sectors which transform raw material to other forms; and tertiary sectors consist of sectors such as transportation, catering, entertainment, and tourism. In this sector, there is not any production of material. Historical experience indicates that as the levels of development of countries increase, the share of agriculture sector in production decreases and the share of service sector increases. Although industry sector reaches to its peak point at one stage of this development at a rate varying between $35 \%$ and $50 \%$ (industrialization period), it starts to decrease later; and service sector becomes the dominant sector in the economy (the period of deindustrialization) (Wrigley, 2004: 291-2). In whole of today's developed countries, the largest component of GDP is service sector.

In the period which lasted until the Industrial Revolution, the active area of activity in the economy was agriculture in all around the world. While the majority of the population was employed in agriculture sector, the 
majority of domestic income consisted of agriculture sector. With Industrial Revolution, some countries such as USA, Germany, Holland, Belgium, France, and primarily Britain started to industrialize rapidly. ${ }^{1}$ In these countries, agriculture sector stopped being the dominant economic activity and service sector has become the dominant area of economic activity in the early periods of industrialization and the next periods of development. For example; while production consisted of $36 \%$, services consisted of $33 \%$, and agriculture consisted of $22 \%$ of the employment in Britain in 1841 , these numbers respectively changed to $18 \%, 81 \%$, and $1 \%$ in $2011^{2}$ Similar tendencies are generally observed in other G-7 countries (Banks et al., 2014). ${ }^{3}$

The growth of service sector in domestic income also reflects on the numbers of employment. After a certain stage of the development, since people start to demand service products rather than material needs, products of service sector become more attractive compared to the products of agriculture and industry sectors. Additionally, mechanization potential in service sector is significantly low. So, employment in service sector starts increasing rapidly (Das and Raut, 2014: 796-797).

As indicated in the report of OECD (2000: 37), service sector dominates our economies and this situation is more likely to continue in the future. Despite this, sector cannot attract the attention as much as it deserves from the political aspect. It is observed that although it has a share less than $20 \%$ in most countries, production industries attract more attention for taxes, trade, and incentives. Though this situation cannot prevent the growth of service sector, lack of interest causes the economic contribution of service sector to stay under its actual potential.

Beyond the wide area it covers in economy, the connection of service sector to other sectors also reveals its importance. Service sector has an important function in the development of an economy for two reasons (Enescu et al., 2014: 116): the first one is that industrialists and exporters cannot become competitive without banking, insurance, accountancy, effective communication, and transportation. The second one is that

\footnotetext{
${ }^{1}$ We cannot count many countries in the group of countries which primarily industrialized. The second group of industrialized countries are the countries which industrialized after World War II. Their numbers are less again.

${ }^{2}$ Office for National Statistics, http://www.ons.gov.uk/, Access Date: 09.03.15.

${ }^{3}$ In this study, data obtained from different sources was used for analysis and comparison. Numbers taken from databases may vary since their methods are different. Since numbers are close to each other in the study, these differences are ignored.
} 
industrialists and exporters cannot have advantage in the comparative superiorities of global world without service sectors.

Contribution of service sector to economy is beyond numeral data. For example, effective financial, transportation, and distribution systems are important for business world and government to carry out their functions. Again in international trade, service sector plays an important role through the support it provides for production industry (OECD, 1999: 7). Service sector can be considered the substructure of economic and social development (Kepenek, 2012: 411).

Although it is highly important in today's economies, it is hard to define service sector since it has a wide area of activity. Service sector comprises of a wide area such as consultancy, informatics, software, transportation, health, education, communication, banking, entertainment, religious services, tourism, and insurance. This wideness and variety causes difficulty in defining the limits of service sector. For this reason, it is easy to define what service sector is not compared to define what service sector is. Service sector comprises all economic fields apart from primary and secondary sectors and in this sense, it can be defined as "residuary sector" (McLachan et al., 2002: 5).

One of the important features of services is that it is economical as well as having social dimensions. In general, quality and quantity of services are also important indicators of economic and social development. It can be stated that the width and depth of individuals' use of services, quality of services, its regional distribution, and relative price are actually intersection points of the economic and social. In addition to this, services are important part of the economy not only through its current or shortterm effects but also through long-term development (Kepenek, 2012: 411).

Although the definition of service sector cannot be completely made, the production carried out in this sector has some features (McLachan et al., 2002: 6): the first one is that service sector is intangible and it does not have a physical existence. The second one is that production in service sector cannot be generally stored or transported. For example, a flight trip, medical care, and haircut cannot be stored and transported. The third one is that there must be a direct relationship between the seller and the buyer in service sector. For example, in order to have dinner at a restaurant or to visit a museum or to watch a football match, one needs to be in the place of production.

The improvement in technology causes service sector's these features to lose its importance. New information and communication technologies 
abolish the obligation of creating a relationship between the consumer and producer such as internet banking, real estate, health care, and distance education. Information-based services have been becoming more mobile day by day (McLachan et al., 2002: 7-8); however, each technology enables service sector to become more common.

These features reveal whether a production belongs to the service sector or not; for example, a tooth filling practiced by a dentist is a service activity. On the other hand, while automobile assembly line is an activity of production part, fixing a car is a part of service sector (Qtd. from Fuchs, 1968 by McLachan et al., 2002: 7).

Since service sector is in a heterogeneous form, it makes it hard to classify the sector. This difficulty brings along different classifications. The classification that McLachan bases on is given below. This classification also complies with NACE (Nomenclature générale des Activités économiques dans les Communautés Européennes"-Statistical Classification of Economic Activities in European Communities) This classification shall be used in the analysis of Turkey.

Since there are a lot of sub-sectors in the table, in order to make the analyses easier, service sector can be divide into two sectors as modern services sector and traditional services sector. Modern services are related to high technology products such as information-communication technologies. They can be transferred electronically. Sectors such as insurance, call centre, desktop publishing, financial analysis, informatics, medical history are analysed in this part.

Traditional part of service sector requires face to face communication. Titles such as transportation, trade, hotel, restaurant, hairdresser, education, public administration, and health services are analysed in this group (Ghani, 2011: 4). Transportation of these services is not possible. In order to use it, one needs to be in the place of production. 
Table 1: The Traditional Industry-Based Classification of Services

\begin{tabular}{|c|c|}
\hline Service Group & Major Activities \\
\hline $\begin{array}{l}\text { Electricity, Gas \& } \\
\text { Water }\end{array}$ & $\begin{array}{l}\text { Electricity and gas supply. Water supply, sewerage and } \\
\text { drainage services. }\end{array}$ \\
\hline Construction & $\begin{array}{l}\text { Building and non-building construction. Also construction } \\
\text { trade services - site preparation, building structure, } \\
\text { installation, building completion and other construction } \\
\text { services. }\end{array}$ \\
\hline Wholesale Trade & $\begin{array}{l}\text { Basic material wholesaling, machinery and motor vehicle } \\
\text { wholesaling, personal and household good wholesaling. }\end{array}$ \\
\hline Retail Trade & $\begin{array}{l}\text { Food retailing, personal and household good retailing, } \\
\text { motor vehicle retailing and services. }\end{array}$ \\
\hline $\begin{array}{l}\text { Accommodation, } \\
\text { Cafes \& Restaurants }\end{array}$ & $\begin{array}{l}\text { Hospitality services including accommodation, pubs, } \\
\text { taverns, bars, cafes, restaurants and clubs. }\end{array}$ \\
\hline Transport \& Storage & $\begin{array}{l}\text { Road, rail, water, air, space and other transport. Services to } \\
\text { transport and storage. }\end{array}$ \\
\hline $\begin{array}{l}\text { Communications } \\
\text { Services }\end{array}$ & Postal, courier and telecommunication services. \\
\hline $\begin{array}{l}\text { Finance \& } \\
\text { Insurance } \\
\end{array}$ & Finance, insurance and services to finance and insurance. \\
\hline $\begin{array}{l}\text { Property \& } \\
\text { Business Services }\end{array}$ & $\begin{array}{l}\text { Property operators and developers, real estate agents, non- } \\
\text { financial asset investors, machinery and equipment hiring } \\
\text { and equipment. Scientific research, technical research, } \\
\text { computer services, legal and accounting services, marketing } \\
\text { and business management services, and other business } \\
\text { services. }\end{array}$ \\
\hline $\begin{array}{l}\text { Government } \\
\text { Administration \& } \\
\text { Defence }\end{array}$ & $\begin{array}{l}\text { Central, state and local government administration, judicial } \\
\text { authorities and commissions, representations of overseas } \\
\text { governments, the Army, Navy and Air Defence forces and } \\
\text { civilian units engaged in defence administration. }\end{array}$ \\
\hline Education & $\begin{array}{l}\text { Preschool, primary and secondary education; post-school } \\
\text { education and other education. }\end{array}$ \\
\hline $\begin{array}{l}\text { Health \& } \\
\text { Community } \\
\text { Services }\end{array}$ & $\begin{array}{l}\text { Hospitals, nursing homes, medical and dental services, } \\
\text { other health services, veterinary services, childcare services } \\
\text { and community care services. }\end{array}$ \\
\hline $\begin{array}{l}\text { Cultural \& } \\
\text { Recreational } \\
\text { Services }\end{array}$ & $\begin{array}{l}\text { Motion pictures, radio and television services, libraries, } \\
\text { museums and the arts, sport, recreation and gambling } \\
\text { services. }\end{array}$ \\
\hline $\begin{array}{l}\text { Personal \& Other } \\
\text { Services }\end{array}$ & $\begin{array}{l}\text { Personal and household goods hiring, other personal } \\
\text { services, religious organisations, interest groups, public } \\
\text { order and safety services, and private households } \\
\text { employing staff }\end{array}$ \\
\hline
\end{tabular}

Source: McLachan et al., 2002: 10. 


\section{Service Sector in Turkey after 2001 Crisis}

Turkey started 1980's with neoliberal economic policies by making a radical change in its economy policies. 1980's is full of practices of these policies. First steps were taken to transit from a planned, importsubstitution, and statist economy to an economy based on free market.

1990's consists of missing years for Turkish economy. Economic development did not occur primarily because of coalition governments as well as some other reasons, and economy of the country experienced crisis many times. One of the most important reasons of this long economic crisis is coalition governments. The period started in October1991 Election became even more unsteady with the death of Özal in 1993. When partners of coalition acted in a populist way in order to come to power alone instead of solving the big economic problems, economy of the country was almost blocked. As a result, instability of growth rates can be seen in Graphic 1. As a consequence of this instability, per capita income which had been 2,791 US dollars in 1990 became 3054 US dollars in 2001.

Graphic 1: GDP's Growth Rate of Turkey (\%)

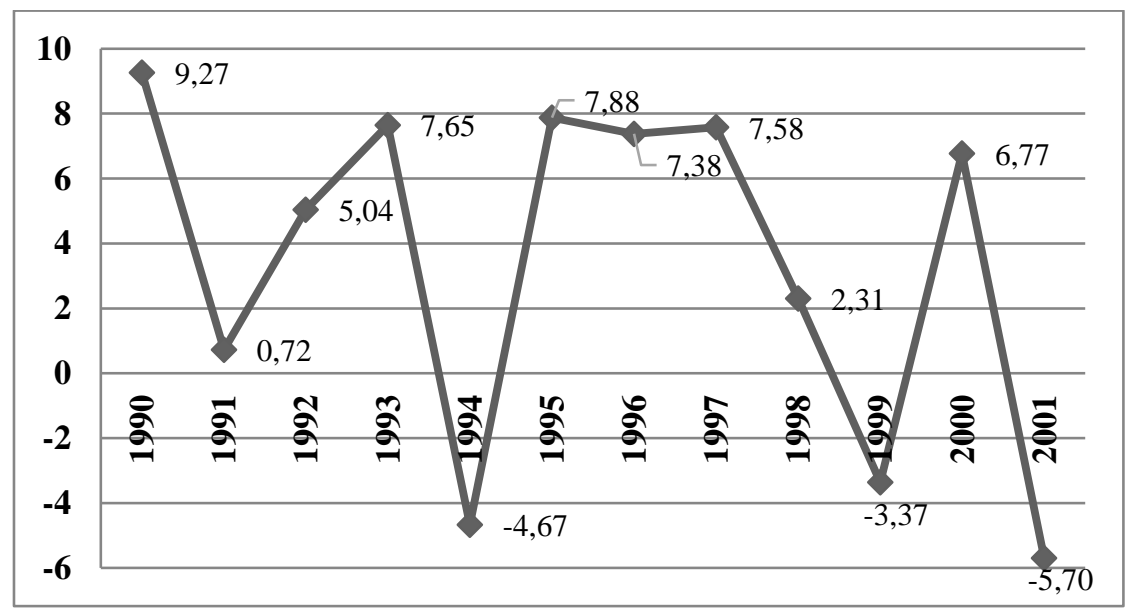

After the crisis occurred in 2001, Transition to the Strong Economy Program started to be implemented. An important difference of TSEP from previous stability programs was that it gave importance to legal regulation and connected that to a calendar. With this aim, a legal regulation calendar was generated for restructuring of financial sector (restructuring of public and private banks), increase of transparency in public sector, strengthening of public funding (borrowing, expropriation and public tender acts, and closing extra-budgetary funds), increasing the 
competitiveness and effectiveness in economy (trustbusting and privatization), and strengthening of social solidarity (precautions aimed at real economy).

After the elections in 2002 and the start of one party government, the country entered into a phase of rapid development until 2009. However, high growth rates could not be achieved after the crisis. Per capita income which exceeds 10,000 US dollars in 2008 could not develop much after this phase.

In the discussed period 2003-2017, GDP increased from 773,26 billion Turkish liras to 1,69 trillion Turkish liras as real; and it showed an increase at the rate of $119 \%$. In this case, annual growth rate was $5.62 \%$. In the same period, service sector increased from 485,9 billion Turkish liras to 1,05 trillion Turkish liras by showing $122 \%$ increase. During this period, the share of service sector in GDP stayed almost stable at the rate of $62 \%$.

Sub-sectors of services are given in the table. Since changes in subsectors of an economy are considered structural changes, 15-year period which shall be analysed in the study is not a period in which important changes occurred in terms of sector shares; however, when it is considered that Turkey is a developing country and there has been an economic stability in 2000's, it can be observed that there have been important changes. In this sense, 15-year period is not a long term but it is not a short term, either.

The biggest sub-sector of service sector is wholesale and retail trade. This sub-sector grew at a rate of $138 \%$ during this period. Its share in GDP in 2003 was $12.1 \%$ but it decreased to $10.7 \%$ in $2009^{4}$; however, later on, it increased up to $11.9 \%$ with a gradual increase. Downsizing occurred in this sector during years of crisis is remarkable.

Transportation and storage is the third sector which has the highest share in GDP with its share of $7.7 \%$. Share of the sector which had been $9.9 \%$ in 2003 decreased to $7.4 \%$ in 2011 by regressing continuously. Although its share in GDP increased in the later period, its share in 2017 was $7.7 \%$. A growth at the rate of $84 \%$ occurred during the period. The fourth biggest sector in service sector is real estate activities sector which showed a low growth rate with $40 \%$. In 2003, its share in GDP was $7.9 \%$ and it reached up to $10.5 \%$ in 2009 , but it decreased to $7.2 \%$ after this

\footnotetext{
${ }^{4}$ Resourse for the sub-sectors GDP rate: Gross domestic product at current prices by kind of economic activity (A21) (value, share, percentage change), at current prices, 1998-2017. 
year. As seen in numbers, the sector experienced a rapid growth until 2009 but after that the growth rate has become significantly slow.

The second biggest of service sector with its share in GDP is construction sector which became the fourth among the most rapidly growing sectors with a growth rate of $254.6 \%$ during the period. Its share in GDP was $4.6 \%$ in 2003 and it reached to $8.6 \%$ in 2017. The rapid growth in construction sector occurred after 2001 Crisis is a well-known issue.

According to NACE coding, it is seen that construction sector has a remarkably wide area: buildings, houses, roads, bridges, airports, railways, subways, service projects, power plants of water and energy, mines etc. Although they are sometimes kept as separate, as a sub-sector of service sector, construction sector has the quality of being a sector which has high re-connection effect in input-output analyses (Atan, 2011: 69). Therefore, the growth of construction sector enables several sectors which provide input to this sector to grow.

In the table, growing financial and insurance activities took the second rank in the most increased sectors with a rate of $295.6 \%$. Growing rapidly Especially in 2008 and 2009, the sector increased its share in GDP, and became the biggest $7^{\text {th }}$ sector in 2017. After the big crisis experienced in 2001, finance sector restructured this sector. When post-1980 Turkish economy is considered, this sub-sector is the sector whose share in GDP increased the most. Another interesting point is that this sector in Turkey was not affected by the financial crisis which affected the whole world.

When it is considered that GDP grew at the rate of $119 \%$ and there was such an increase in finance and insurance sector in this period, such rapid growth of finance and insurance sector in Turkey also brings along financialization criticisms which are known as that finance sector becomes independent from real sector and takes real sector under its control in time (Aybar and Doğru, 2013). However, Turkey's speed of financialization is significantly less than the average of developed countries. Additionally, finance sector was reinforced through structural measures taken after 2001 crisis.

Both qualitative and quantitative amelioration of education is an inevitable condition for the development of not only service sector but also the whole economy. It is known that education increases the addedvalue during the process of production; however, as a sub-sector of service sector, education is considered a sector where added-value is produced. 
Table 2: The Distribution of Service Sector

\begin{tabular}{|c|c|c|c|c|c|c|c|c|c|}
\hline Sub-s & & 2003 & 2005 & 2007 & 2009 & 2011 & 2013 & 2015 & 2017 \\
\hline \multirow{3}{*}{ Construction } & 1 & 64,4 & 89,8 & 124,7 & 100 & 146,1 & 180,4 & 198,7 & 228,2 \\
\hline & 2 & 36,1 & 50,4 & 70 & 56,2 & 82,1 & 101,3 & 111,6 & 128,2 \\
\hline & & 13,8 & 15 & 10,6 & $-15,9$ & 24,7 & 14 & 4,9 & 9 \\
\hline \multirow{3}{*}{$\begin{array}{l}\text { Wholesale and retail } \\
\text { trade }\end{array}$} & 1 & 80,4 & 102,1 & 115,2 & 100 & 130,3 & 144,7 & 168,6 & 191,5 \\
\hline & 2 & 85,9 & 109,1 & 123 & 106,8 & 139,1 & 154,6 & 180,1 & 204,5 \\
\hline & 3 & 12,3 & 10,6 & 5,9 & -12 & 14,6 & 7,8 & 7,7 & 10,9 \\
\hline \multirow{3}{*}{$\begin{array}{l}\text { Transportation and } \\
\text { storage }\end{array}$} & & 81,5 & 98 & 110,8 & 100 & 107,6 & 127,8 & 141,6 & 154,3 \\
\hline & & 71,5 & 86,1 & 97,3 & 87,8 & 94,5 & 112,2 & 124,3 & 135,5 \\
\hline & 3 & 7,9 & 9,7 & 6,1 & $-9,6$ & 6,6 & 3,7 & 6 & 9,8 \\
\hline \multirow{3}{*}{$\begin{array}{l}\text { Accom. and food } \\
\text { service activities }\end{array}$} & & 93,1 & 98,8 & 101,9 & 100 & 133 & 157,4 & 176,5 & 188,2 \\
\hline & & 21,2 & 22,5 & 23,2 & 22,8 & 30,3 & 35,8 & 40,2 & 42,9 \\
\hline & J & $-6,9$ & $-0,2$ & 1,2 & 1,5 & 22,5 & 9,3 & 3,7 & 14 \\
\hline \multirow{3}{*}{$\begin{array}{l}\text { Information and } \\
\text { communication }\end{array}$} & 1 & 61,5 & 85,4 & 97,5 & 100 & 108,2 & 128,1 & 142,6 & 170,8 \\
\hline & 2 & 16,7 & 23,2 & 26,5 & 27,2 & 29,4 & 34,8 & 38,7 & 46,4 \\
\hline & J & 6,4 & 19,5 & 9 & -2 & 8,6 & 8,9 & 3,8 & 13,1 \\
\hline \multirow{3}{*}{$\begin{array}{l}\text { Financial and } \\
\text { insurance activities }\end{array}$} & 1 & 48,8 & 60,9 & 67,6 & 100 & 113,6 & 143,2 & 171 & 193,1 \\
\hline & & 18,3 & 22,8 & 25,3 & 37,5 & 42,6 & 53,6 & 64 & 72,4 \\
\hline & J & $-3,9$ & 10,4 & 6,1 & 30,2 & 5 , & 25,8 & 8,4 & 3 , \\
\hline \multirow{3}{*}{ Real estate activities } & & 93,3 & 97,8 & 99,8 & 100 & 109,7 & 117,7 & 123,6 & 131 \\
\hline & 2 & 97,8 & 102,5 & 104,6 & 104,8 & 115 & 123,4 & 129,5 & 137,6 \\
\hline & $\therefore$ & 1,4 & 2,3 & 0,8 & $-0,2$ & & 2,9 & 2,4 & 2, \\
\hline \multirow{3}{*}{$\begin{array}{l}\text { Professional, } \\
\text { scientific and } \\
\text { technologic activities }\end{array}$} & & 57,5 & 71,9 & 92 & 100 & & 135,5 & 169,8 & 18 \\
\hline & & 12,4 & 15,5 & 19,9 & 21,6 & & 29,3 & 36,7 & 40 \\
\hline & 3 & 4,2 & 10,4 & 13,8 & 2,9 & & 7,8 & 16,5 & 10,7 \\
\hline \multirow{3}{*}{$\begin{array}{l}\text { Administration and } \\
\text { support service } \\
\text { activities }\end{array}$} & 1 & 64,4 & 80,8 & 99,7 & 100 & 116,9 & 149,9 & 194,6 & 234,8 \\
\hline & 2 & 14,8 & 18,5 & 22,8 & 22,9 & 26,8 & 34,4 & 44,6 & 53,8 \\
\hline & 3 & 8,5 & 11,2 & 11,2 & $-3,2$ & 16,3 & 16,6 & 14,6 & 10,2 \\
\hline \multirow{3}{*}{$\begin{array}{l}\text { Public } \\
\text { administration and } \\
\text { defence; compul-sory } \\
\text { social security }\end{array}$} & 1 & 98,3 & 97 & 98,4 & 100 & 101,5 & 110,1 & 116,2 & 128,1 \\
\hline & - & 49,3 & 48,7 & 49,4 & 50,2 & 51 & 55,3 & 58,3 & 64,3 \\
\hline & $\mathbf{J}$ & $-0,6$ & $-4,6$ & 1,3 & 1,7 & & 4,2 & & \\
\hline \multirow{3}{*}{ Education } & 1 & 80,9 & 86,9 & 97,1 & 100 & 108,1 & 122,9 & 136,8 & 147 \\
\hline & 2 & 31,7 & 34 & 38 & 39,1 & 42,3 & 48,1 & 53,5 & 57,5 \\
\hline & 3 & 0,8 & 5,4 & 5,7 & 1,4 & 5,1 & 8,8 & 3,2 & 4,8 \\
\hline \multirow{3}{*}{$\begin{array}{l}\text { Human health and } \\
\text { social work }\end{array}$} & 1 & 64,6 & 80,8 & 90,7 & 100 & 110,9 & 121,4 & 124,7 & 136,7 \\
\hline & 2 & 19 & 23,7 & 26,7 & 29,4 & 32,6 & 35,7 & 36,7 & 40,2 \\
\hline & 3 & 4,3 & 22,5 & 4,9 & 4,2 & 8,2 & 6,1 & 1,6 & 1,9 \\
\hline \multirow{3}{*}{$\begin{array}{l}\text { Arts, entertain. and } \\
\text { recreation }\end{array}$} & 1 & 21,8 & 34 & 71 & 100 & 118,1 & 143,8 & 160,2 & 172,5 \\
\hline & 2 & 1,9 & 2,9 & 6,1 & 8,5 & 10,1 & 12,3 & 13,7 & 14,7 \\
\hline & 3 & 3,4 & 42,3 & 37,6 & 12,1 & 10,3 & 15,5 & 4,4 & 6,4 \\
\hline \multirow{3}{*}{$\begin{array}{l}\text { Other service } \\
\text { activities }\end{array}$} & 1 & 88,7 & 92,9 & 101,9 & 100 & 120,9 & 128,6 & 131,4 & 147,8 \\
\hline & 2 & 9,2 & 9,6 & 10,6 & 10,4 & 12,5 & 13,3 & 13,6 & 15,3 \\
\hline & & 0,6 & 2,6 & 3,9 & $-2,2$ & 15,1 & 2,3 & $-4,6$ & 8,2 \\
\hline
\end{tabular}

Source: Chained volume by sectors (2009 based, 1998-2017). 
In the period of 2003-2017, growing more rapidly than other sectors, education sector increased its shared in GDP to $4.1 \%$ in 2017, which had been $3.2 \%$ in 2003. In this context, its share in GDP increased although it is minor. Education sector grew at low rates but in a stable manner. It reveals that education sector has not been affected by the crises in Turkey.

The sector which showed the most rapid increase among the sectors during this period is the sub-sector of culture, art, entertainment, recreation, and sports with a rate of $692 \%$. Thanks to this rapid increase, its share in GDP reached to $0.9 \%$ in 2017 , which was $0.2 \%$ in 2003 . The most important quality of accommodation and food activities sector is that it includes tourism sector, which has been rapidly growing after 1980's, within itself at a large scale. For this reason, in some studies, this sector is considered the one representing tourism sector. This sector became one of the sectors which experienced the least added-value increase in the relevant period. The increase is $102 \%$ in 15 -year period.

In the period of 2003-2017, the least growth was experienced in the subsector of public administration and defence, compulsory social security with a rate of $30.36 \%$. The share of sector in GDP decreased from $5.4 \%$ to $4.3 \%$.

\section{External Balance of Service Sector}

In 1990's when service sector became the dominant area of activity, globalization also started to accelerate. In this scope, the share of service sector in world trade has increased with the developing technology and the opportunities it has brought along. In these years, people started to emphasize that service sector should be liberalized.

Countries which have external deficit in merchandise trade of balance of international payments shall have external surplus in service trade; and countries which have external surplus in merchandise trade shall have external deficit in service trade. While countries such as USA, and Britain have external surplus in service trade, countries such as Germany, Japan, and China have external deficit in service trade (Barattieri, 2014).

Being among the first group countries, while foreign trade deficit has become chronic in Turkey, it started to have external surplus in service trade which has been developing since 1980's. While services balance had 10.4 billion dollars surplus in 2003, this amount reached to 24.7 billion dollars in 2017 . 
When foreign trade is considered, sub-sectors which provide the real income in service sector are travel and transportation sectors. While the net travel income referring to tourism activities was 11 billion dollar in 2003, it reached to 17.66 billion dollars in 2017. Travel activities contributed to foreign trade and economy with 24.48 billion dollars in 2014. Net income obtained from tourism sector constitutes almost all net income of service sectors. Transportation and construction service sectors follow travel sector in terms of the contribution to the economy.

Table 3: External Balance of Service Sector (Million Dollar)

\begin{tabular}{|c|c|c|c|c|c|c|c|c|c|c|c|}
\hline & 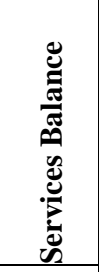 & 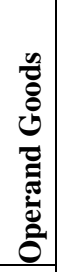 & 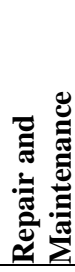 & 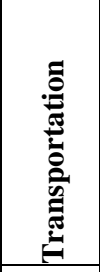 & 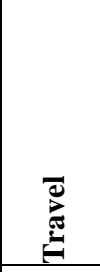 & 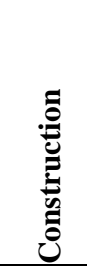 & 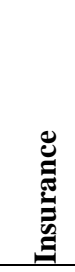 & 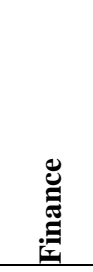 & 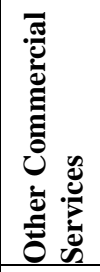 & 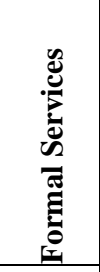 & $\frac{\dot{d}}{\tilde{0}}$ \\
\hline 2003 & 10.394 & 0 & 0 & -523 & 11.051 & 682 & 0 & -83 & -104 & -708 & 79 \\
\hline 2004 & 12.732 & 0 & 0 & -1.143 & 13.597 & 724 & 0 & -89 & -169 & -721 & 533 \\
\hline 2005 & 15.872 & 0 & 0 & -70 & 16.087 & 874 & 0 & -41 & -344 & -874 & 240 \\
\hline 2006 & 13.897 & 0 & 0 & 294 & 14.468 & 879 & -604 & -247 & -598 & -842 & 547 \\
\hline 2007 & 14.089 & 0 & 0 & -431 & 15.781 & 759 & -885 & -228 & -839 & -579 & 511 \\
\hline 2008 & 18.908 & 0 & 0 & 246 & 19.541 & 974 & -703 & -133 & -1.146 & -649 & 778 \\
\hline 2009 & 18.728 & 0 & 0 & 1.838 & 18.405 & 1.090 & -554 & -355 & -1.369 & -656 & 329 \\
\hline 2010 & 16.749 & 0 & 0 & 1.340 & 17.391 & 859 & -541 & -234 & -1.428 & -714 & 76 \\
\hline 2011 & 20.288 & 63 & -86 & 2.401 & 20.171 & 838 & -472 & -690 & -1.529 & -891 & 483 \\
\hline 2012 & 22.541 & 60 & -136 & 3.699 & 21.251 & 1.029 & -476 & -642 & -1.724 & -805 & 285 \\
\hline 2013 & 23.618 & 97 & -197 & 3.959 & 23.180 & 675 & -787 & -555 & -2.158 & -702 & 106 \\
\hline 2014 & 26.675 & 72 & -254 & 5.460 & 24.480 & 1.084 & -629 & -1.079 & -2.017 & -1.208 & 766 \\
\hline 2015 & 24.228 & 67 & -315 & 6.182 & 21.248 & 375 & -437 & -1.121 & -1.513 & -1.076 & 818 \\
\hline 2016 & 15.263 & -3 & -316 & 5.033 & 13.960 & 512 & -517 & -934 & -1.718 & -1.172 & 418 \\
\hline 2017 & 19.938 & 41 & -298 & 5.397 & 17.655 & 438 & -765 & -561 & -1.624 & -778 & 433 \\
\hline 2018 & 24.694 & 50 & -410 & 7.433 & 20.625 & 303 & -492 & -695 & -1.518 & -818 & 216 \\
\hline
\end{tabular}

Source: TCMB, Statistics of Balance of Payment, EVDS. 


\section{Sectoral Distribution of Employment in Turkey}

As transition from agricultural society to industrial society required an increase in the stock of human capital, service sector also requires an increase in human capital in order to become the dominant sector and maintain this position. It is possible through education; however, education has continued to be a chronic problem of Turkey both qualitatively and quantitatively. Turkey has the same Human Development Index (HDI) as countries which have almost half of per capita income of Turkey because of the regression in numbers of education.

In the period of 2003-2017, schooling rates in Turkey were always getting higher in terms of quantity. Gross rate of schooling in primary education is $100 \%$ both in the beginning and at the end of terms. In 2002, gross rate of schooling in secondary education increased from $80.8 \%$ to $100 \%$. In the same period, gross rate of schooling in higher education increased from $35.8 \%$ to $100 \%$. Similar ameliorations were observed in the number of students, teachers, and classroom, and in the number student per teacher (TÜIK, Statistics in Education).

However, when the quality of this numeral development is considered, it is seen that the development is slow. For example, when PISA exam results are compared, it is observed that the scores of Turkish students are under the average score of OECD countries (Yardımcıoglu and Yıldırım, 2013).

Related to this situation in education indicators, it is observed that there are important differences between sectoral distribution of employment and sectoral distribution of GDP in Turkey. In 2002, although the share of agriculture in GDP was 10.3, it provided 34.9 of employment. In the same year, these numbers are respectively $24.6 \%$ and $23 \%$ in industry sector; and $53.4 \%$ and $42.1 \%$ in service sector. While the share of agriculture in employment decreased to $19.4 \%$ in 2017 , the share of industry increased to $26.8 \%$, and the share of services increased to $53.8 \%$.

5 T.R. Presidency, Department of Strategy and Budget, Gross Rates of Schooling.

$640 \%$ of this rate is in formal education and $60 \%$ of it is in distance education. 
Graphic 2: Sectoral Distribution of Employment in Turkey

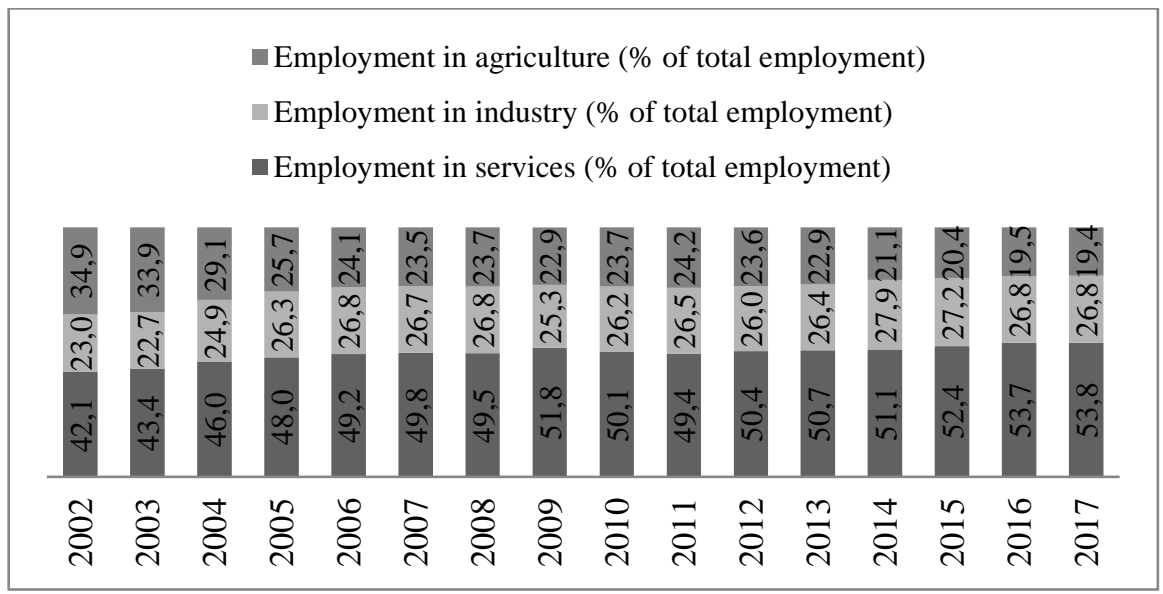

Source: World Bank Development Indicators

\section{Comparison of Service Sectors in Turkey and Selected Countries}

It is hard to make comparisons between countries in terms of economics because histories, social structures, and economic institutions of countries are different from each other. This difficulty increases even more when the issue is service sector. When the issue is service sector, there might be very different situations between countries which are close to each other geographically and have similar institutions.

In the following graphic, some developed and developing countries are compared. When Japan, Germany, France, Britain, and USA are compared, it is observed that the share of agriculture in GDP is low in these three countries. However, while the share of services in GDP in France, Britain, and USA is around $78 \%$, this rate is $73.2 \%$ in Japan, and $68.4 \%$ in Germany. In order to understand how important these differences are, one needs to take a look at current prices. For example, while Britain produced 481 billion dollars added-value in production sector in 2013, this amount exceeded 1 trillion dollars in Germany in the same year. While 28.684 dollars of service added value were produced per person in Germany in 2003, this rate was 29.460 dollars in Britain (WDI).

A similar comparison can be carried out in the world's two rapidly growing economies which are China and India. When sector shares of these two countries are considered, it is observed that their development 
paths are different. While China is growing based on industry sector, India is growing based on service sector.

When other developing countries such as Brazil, Russia, and Turkey are compared, it is seen that the share of industry sector in GDP is higher in Russia, and the situation is similar in Turkey and Brazil.

Graphic 3: Sectoral Distribution of Economies of Some Countries

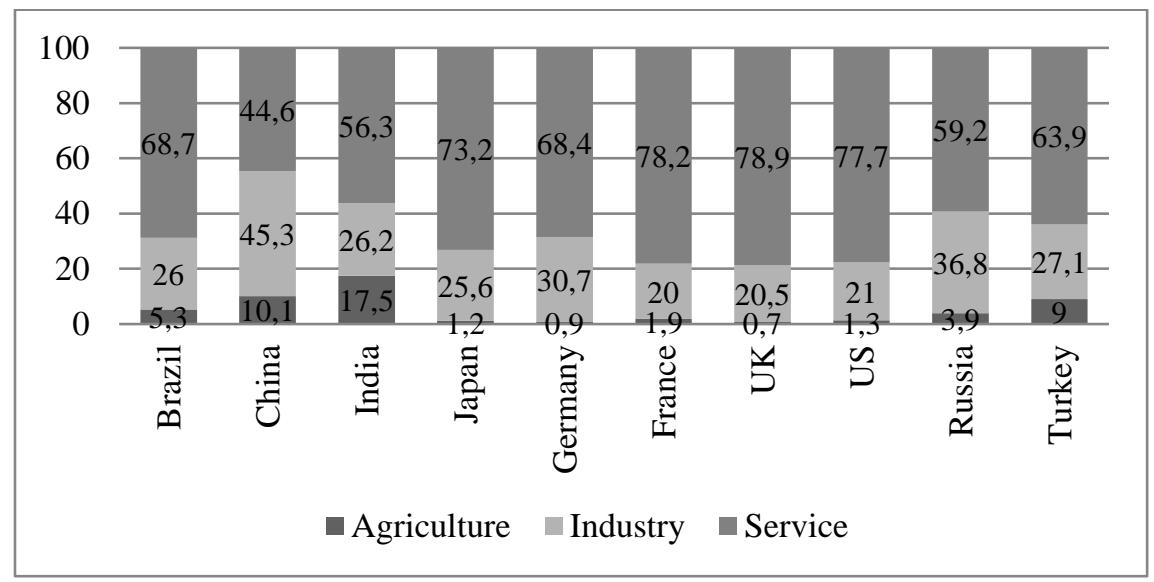

Source: World Bank Development Indicators

\section{Conclusion}

It is hard to define service sector since it has a wide area of activity such as consultancy, informatics, software, transportation, health, education, communication, banking, entertainment, religious services, tourism, and insurance. For this reason, service sector is not defined by what it is but it is defined by what it is not: defined as all economic activities apart from agriculture and industry sector.

Although industry sector comes forth when the issue is taxes, trade, and incentives, in modern economies, service sector has the biggest share in GDP. This share reaches up to $80 \%$ in some countries. Since service sector does not find the place it deserves in economy theory, it stays under its potential.

Contribution of service sector to economy is beyond numeral data. For agriculture and industry sectors to be more effective in an economy, finance, transportation, insurance, and distribution systems should be more qualified. Again in international trade, service sector provides support to production and agriculture industry. Service sector can be considered the substructure of economic and social development. 
Although service sector has continuously grown during the history of Turkish Republic, its real progress has occurred after 1980's. Although Turkey left its statist policies that it had implemented before after this date, service sector has still fallen behind of similar countries since it experienced many crises until 2001.

When sub-sectors of service sector in Turkey are considered, the first three ranks in terms of the share in GDP consist of respectively wholesale and retail trade, construction and transportation, and storage sectors. After 2001 Crisis, construct sector has gradually increased in the economy. Similar numbers can be observed in the share of service sector in employment. However, when the issue is external balance which shows the real competitive power of a sector, the significant sectors are transportation and travel sectors. These sectors have the important part of the economy in foreign trade balance.

When other countries are considered, France, Britain and USA which are also called post-industrial economies have covered a distance to become services society. Being among the middle income countries, the share of service sector in the economy in Turkey is far behind these countries.

\section{References}

Atan, S. (2011), Türkiye'deki Sektörel Bağlantı Yapısının Girdi-Çıktı Yaklaşımı ile İncelenmesi: Yurtiçi Üretim ve İthal Ara Girdi Ayrıştırması, Ekonomik Yaklaşım, 22(80), p. 59-78.

Aybar, S. and Doğru, C. (2013), Finansallaşma ve İktisadi Sonuçları: Türkiye Örneği, Maliye Finans Yazıları, 27(100), p. 9-40.

Banks, A., Sami, H., Taylor, C. and Hardie, M. (2014), An International Perspective on the UK-Gross Domestic Product, http://www.ons.gov.uk/ons/dcp171766_360847.pdf. Access Date: 09.03.2015.

Das, Lawly and Raut, R. (2014), Impact of Changes in Service Sector in India in Shaping the Future of Business and Society, Procedia Economics and Finance, 11, p. 795-803.

World Bank Development Indicators, http://databank.worldbank.org/.

Erdoğdu, S. and Toksöz, G. (2013), Kadınların Görünmeyen Emeğinin Görünen Yüzü: Türkiye'de Ev Işçileri, Ankara: Uluslararası Çalışma Örgütü.

Ghani, E. (2011), Service Revolution, http://www.ilo.org/, Access Date: 29.03.2015. 
Inman, R. P. (ed). (1985), Managing the Sevice Economy: Prospects and Problems, New York: Cambridge University Press, ABD.

Kepenek, Y. (2012), Türkiye Ekonomisi, İstanbul: Remzi Kitabevi.

McLachan, R., Clark, C. and Monday, I. (2002), Australia'a Service Sector: A Study in Diversity. Canberra: Australia Productivity Commision Research Paper.

MEB, Milli Eğitim İstatistikleri, http://sgb.meb.gov.tr/, Access Date: 31.03.2015.

OECD (1999), Business and Industry Policy Forum on the Services Economy: Background Report, DSTI/IND (99) 19.

OECD (2000), The Service Economy, Business and Industry Policy Forum Series, Paris.

Taşkesenlioğlu, Z. (2010), Hizmet Sektörü Raporu, İstanbul: MÜSİAD Araştırma Raporları.

TCMB, Balance Payment Istatistics, EVDS, Acces Date: 31.03.2019.

TÜİK (2013), NACE Rev.2. Ankara: Alt1lı Ekonomik Faaliyet Siniflamas1.

TÜİK, Eğitim İstatistikleri, www.tuik.gov.tr, Access Date: 30.03.2015.

TÜİK, Gayri Safi Yurtiçi Hasıla ve Kişi Başına Gayri Safi Yurtiçi Hasıla, www.tuik.gov.tr, Access Date: 23.03.19.

TÜİK, Gayrisafi Yurtiçi Hasıla, Iktisadi Faaliyet Kollarına (A21) Göre Cari Fiyatlarla (değer, pay, değişim oranı), 1998-2017, www.tuik.gov.tr, Access Date: 23.03.19.

TÜİK, İstihdam Edilenlerin Yıllara Göre İktisadi Faaliyet Kolları ve Dağılımı, NACE Rev.2, www.tuik.gov.tr, Access Date: 23.03.19.

Ulaştırma, Denizcilik ve Haberleşme Bakanlığı (no date) 2003-2013 Istatistiklerle Ulaştırma, Denizcilik ve Haberleşme, Ankara.

Wrigley, E. A. (2004), Poverty, Progress and Population, Cambridge: Cambridge University Press, UK.

Yardımcığlu, F. and Yıldırım, C. (2013), OECD ve AB Ülkelerinin Eğitim Göstergelerinin Türkiye ile Karşılaştırmalı Bir Analizi, (Eds: Yıldırım Turan, Alâeddin Yalçınkaya ve Ertan, Siyaset, Ekonomi ve Toplum Üzerine 3. Uluslararası Mavi Karadeniz Kongresi: Uyuşmazlık Çözümü, İşbirliği ve Demokratikleşme. 
